\title{
Abnormal GABA Receptor-Mediated Currents in Dorsal Root Ganglion Neurons Isolated from Na-K-2Cl Cotransporter Null Mice
}

\author{
Ki-Wug Sung, ${ }^{1,3}$ Michael Kirby, ${ }^{2}$ Michael P. McDonald,2 David M. Lovinger, ${ }^{1,2,3}$ and Eric Delpire ${ }^{1,3}$ \\ Departments of ${ }^{1}$ Anesthesiology, ${ }^{2}$ Pharmacology, and ${ }^{3}$ Molecular Physiology and Biophysics, Center for Molecular \\ Neuroscience and Kennedy Center for Research on Human Development, Vanderbilt University Medical Center, Nashville, \\ Tennessee 37232
}

\begin{abstract}
We have recently disrupted S/c12a2, the gene encoding the secretory $\mathrm{Na}-\mathrm{K}-2 \mathrm{Cl}$ cotransporter in mice (NKCC1) (Delpire et al., 1999). Gramicidin perforated-patch and whole-cell recordings were performed to study GABA-induced currents in dorsal root ganglion (DRG) neurons isolated from wild-type and homozygote NKCC1 knock-out mice. In wild-type DRG neurons, strong GABA-evoked inward current was observed at the resting membrane potential, suggesting active accumulation of $\mathrm{Cl}^{-}$in these cells. This GABA-induced current was blocked by picrotoxin, a $\mathrm{GABA}_{\mathrm{A}}$ receptor blocker. The strong $\mathrm{Cl}^{-}$accumulation that gives rise to depolarizing GABA responses is caused by $\mathrm{Na}-\mathrm{K}-2 \mathrm{Cl}$ cotransport because reduction of external $\mathrm{Cl}^{-}$or application of bumetanide induced a decrease in $\left[\mathrm{Cl}^{-}\right]_{\mathrm{i}}$, whereas an increase in external $\mathrm{K}^{+}$caused an apparent $\left[\mathrm{Cl}^{-}\right]_{\mathrm{i}}$ accumulation. In contrast to control neurons, little or no net current was
\end{abstract}

observed at the resting membrane potential in homozygote NKCC1 mutant DRG neurons. $E_{\mathrm{GABA}}$ was significantly more negative, demonstrating the absence of $\mathrm{Cl}^{-}$accumulation in these cells. Application of bumetanide induced a positive shift of $E_{\mathrm{GABA}}$, suggesting the presence of an outward $\mathrm{Cl}^{-}$transport mechanism. In agreement with an absence of GABA depolarization in DRG neurons, behavioral analysis revealed significant alterations in locomotion and pain perception in the knock-out mouse. Our results clearly demonstrate that the $\mathrm{Na}-\mathrm{K}-2 \mathrm{Cl} \mathrm{co}-$ transporter is responsible for $\left[\mathrm{Cl}^{-}\right]_{\mathrm{i}}$ accumulation in DRG neurons and that via regulation of intracellular $\mathrm{Cl}^{-}$, the $\mathrm{Na}-\mathrm{K}-2 \mathrm{Cl}$ cotransporter participates in the modulation of GABA neurotransmission and sensory perception.

Key words: Na-K-2Cl cotransporter; knock-out mouse; dorsal root ganglion; bumetanide; chloride; GABA; nociception
GABA, via hyperpolarization of postsynaptic membranes, acts as an inhibitory neurotransmitter in the adult CNS. However, in several adult sensory neurons, GABA elicits depolarizing responses. GABAergic terminals, mostly from interneurons, are presynaptic to central terminals of muscle and nociceptive afferent fibers ending in the dorsal columns of the spinal cord. The release of GABA by interneurons depolarizes the terminals of these primary afferent fibers leading to presynaptic inhibition. Presynaptic inhibition is thought to reduce or eliminate sensory "noise" originating from second-order neurons, enhancing sensory contrast and allowing only the passage of more potent sensory inputs (Willis, 1999). Thus, GABA via primary afferent depolarization and presynaptic inhibition participates in the modulation of excitability of the sensory terminals of both large (muscle) and fine (nociceptive, touch, and temperature) fibers.

Microelectrode and gramicidin perforated-patch studies in amphibian dorsal root ganglion (Alvarez-Leefmans et al., 1988) and spinal cord (Rohrbough and Spitzer, 1996) demonstrated a high intracellular $\mathrm{Cl}^{-}$concentration in primary sensory neurons. High neuronal $\mathrm{Cl}^{-}$concentration is consistent with GABA depolarization and presynaptic inhibition (for review, see Alvarez-Leefmans et al., 1998). Accumulation of $\mathrm{Cl}^{-}$in these cells was shown to be $\mathrm{Na}^{+}$and $\mathrm{K}^{+}$dependent and sensitive to the loop diuretic bumetanide, three hallmarks of $\mathrm{Na}-\mathrm{K}-2 \mathrm{Cl}$ cotransport.

Electrically silent coupled movement of $\mathrm{Na}^{+}, \mathrm{K}^{+}$, and $\mathrm{Cl}^{-}$ across biological membranes occurs via two isoforms of the $\mathrm{Na}-$

\footnotetext{
Received May 23, 2000; revised July 13, 2000; accepted Aug. 9, 2000.

This work was supported in part by the National Institute of Neurological Disorders and Stroke Grant NS 36758, by a Vanderbilt University Medical Center Intramural Discovery Grant to E.D., and by the National Institute on Alcohol Abuse and Alcoholism Grant AA 08986 to D.M.L. K.-W.S. was supported by a Korean Science and Engineering Foundation (KOSEF) grant. E.D. is an Established Investigator of the American Heart Association.

Correspondence should be addressed to Dr. Eric Delpire, Anesthesiology Research Division, Department of Anesthesiology, Vanderbilt University, T-4202, Medical Center North, Nashville, TN 37232-2520. E-mail: eric.delpire@mcmail.vanderbilt.edu. Copyright (C) 2000 Society for Neuroscience $0270-6474 / 00 / 207531-08 \$ 15.00 / 0$
}

K-2Cl cotransporter: NKCC1 (Slc12a2 gene) and NKCC2 (Slc12al gene). NKCC2 is exclusively expressed in the kidney, whereas $\mathrm{NKCC} 1$ exhibits a wide pattern of expression that ranges from $\mathrm{Cl}^{-}$-secreting epithelia to red blood cells, myocytes, and neurons (for review, see Haas and Forbush, 1998; Mount et al., 1998).

Using a polyclonal antibody directed against a C-terminal region of the NKCC1 protein (Kaplan et al., 1996), we demonstrated high levels of cotransporter expression in rat dorsal root ganglion neurons (Plotkin et al., 1997a), suggesting an important role for the cotransporter in accumulating $\left[\mathrm{Cl}^{-}\right]_{\mathrm{i}}$ in mammalian sensory neurons.

In this study, we take advantage of a mouse knock-out model of the $\mathrm{Na}-\mathrm{K}-2 \mathrm{Cl}$ cotransporter that we developed recently (Delpire et al., 1999) to examine the role of the cotransporter in regulating $\left[\mathrm{Cl}^{-}\right]_{\mathrm{i}}$ in dorsal root ganglion neurons. We show that absence of the $\mathrm{Na}-\mathrm{K}-2 \mathrm{Cl}$ cotransporter dramatically affects the reversal potential of GABA-mediated responses via a significant reduction in basal $\mathrm{Cl}^{-}$concentration. The strong depolarizing responses elicited by the $\mathrm{GABA}_{\mathrm{A}}$ receptor in control mice turned into mild depolarizing or even hyperpolarizing responses in the $\mathrm{NKCC} 1$ knock-out mice. In agreement with these abnormal GABA responses in sensory neurons, we show that N KCC1 knock-out mice display both abnormal gait and locomotion as well as impaired nociception phenotypes. These experiments clearly demonstrate that the $\mathrm{Na}-\mathrm{K}-2 \mathrm{Cl}$ cotransporter accumulates $\mathrm{Cl}^{-}$in mouse dorsal root ganglion (DRG) neurons and that no other $\mathrm{Cl}^{-}$transport pathways are present in these cells to achieve this function. $\mathrm{Cl}^{-}$ accumulation by the $\mathrm{Na}-\mathrm{K}-2 \mathrm{Cl}$ cotransporter is a key component of GABA depolarization and modulation of sensory input to the spinal cord.

\section{MATERIALS AND METHODS}

$\mathrm{Na}-\mathrm{K}-2 \mathrm{Cl}$ cotransporter knock-out mice. Slc12a $2^{-/}-\left(\mathrm{NKCC1}^{-/-}\right)$mice were obtained by deletion of exon 9 of the $\mathrm{Na}-\mathrm{K}-2 \mathrm{Cl}$ cotransporter gene and replacement with a $\beta$-galactosidase/neomycin fusion cassette (Delpire et al., 1999). The disrupted gene was integrated by recombination in L129 
embryonic stem cells and propagated into C57b6 mice. Homozygote animals survive and exhibit multiple phenotypes. They are smaller in size, are hypotensive, present impaired epithelial $\mathrm{Cl}^{-}$secretion, and present inner ear defects resulting in significant impairment of locomotion as well as deafness (Delpire et al., 1999; Flagella et al., 1999). Animals used in this study were 6-12 weeks old.

Immunofluorescence. Dorsal root ganglia, isolated from control and homozygote mice, were fixed overnight at $4^{\circ} \mathrm{C}$ with $4 \%$ paraformaldehyde, washed with PBS, and cryoprotected with 30\% sucrose. For indirect immunofluorescence, $7-\mu \mathrm{m}$-thick frozen sections were thaw mounted on Superfrost Plus slides. The sections were treated with $1 \%$ SDS and $8 \%$ 2-mercaptoethanol for $5 \mathrm{~min}$ and then washed in PBS and 1\% BSA at room temperature for $30 \mathrm{~min}$, followed by incubation with affinity-purified antibody (Kaplan et al., 1996; Plotkin et al., 1997a, b) at a dilution of 1:200 in PBS and $1 \%$ BSA overnight at $4^{\circ} \mathrm{C}$. After washes in PBS, slides were incubated with indocarbocyanine-conjugated goat anti-rabbit IgG (Jackson ImmunoResearch, West Grove, PA) diluted 1:800 in PBS and 1\% BSA for $1 \mathrm{hr}$ at room temperature, washed with PBS, and mounted with Vectashield (Vector Laboratories, Burlingame, CA). Sections were analyzed with a Nikon Eclipse E800 microscope equipped with an Optronics DEI750 color CCD camera (Optronics Engineering, Goleta, CA) coupled to an IBM-compatible computer. Photographs were obtained with a color Tektronix Phaser 450 printer (Tektronics, Wilsonwill, OR).

$D R G$ neuron isolation. Wild-type and homozygote mice were killed by cervical dislocation. DRGs were dissected from the lower thoracic to midlumbar regions of the vertebral column and placed in oxygenated DMEM (Life Technologies, Gaithersburg, MD). The connective tissue sheath around the ganglia was removed, and DRGs were minced two to three times with iridectomy scissors. The minced DRGs were then placed in a flask containing $5 \mathrm{ml}$ of DMEM containing $1 \mathrm{mg} / \mathrm{ml}$ collagenase D (Boehringer Mannheim, Indianapolis, IN), $0.6 \mathrm{mg} / \mathrm{ml}$ deoxyribonuclease I (DNase; Sigma, Saint Louis, MO), and $0.6 \mathrm{mg} / \mathrm{ml}$ trypsin (Sigma). DRGs were incubated at $37^{\circ} \mathrm{C}$ in a shaking water bath for $30-40 \mathrm{~min}$. At the end of the incubation period, $1 \mathrm{mg} / \mathrm{ml}$ soybean trypsin inhibitor (Sigma) was added, and individual neurons were isolated from the ganglia by vigorous shaking. Neurons were kept at room temperature $\left(20-22^{\circ} \mathrm{C}\right)$ in the DMEM solution and were aliquoted as needed to $35 \mathrm{~mm}$ culture dishes.

Recording. Electrophysiological responses were recorded using the gramicidin perforated-patch whole-cell recording technique with an Axopatch 1D amplifier (Axon Instruments, Foster City, CA) and pClamp 6 software (Axon Instruments). DRG neurons were allowed to settle in a $35 \mathrm{~mm}$ culture dish placed onto an inverted microscope (Zeiss). After attachmen to the dish $(30 \mathrm{~min})$, an external solution was perfused at a rate of 1.5-2.0 $\mathrm{ml} / \mathrm{min}$. The solution contained $150 \mathrm{~mm} \mathrm{NaCl}, 5 \mathrm{~mm} \mathrm{KCl}, 0.5 \mathrm{mM} \mathrm{CaCl}_{2}$, $1 \mathrm{~mm} \mathrm{MgCl}, 10 \mathrm{~mm}$ glucose, and $10 \mathrm{~mm}$ HEPES, $\mathrm{pH}$ 7.4. Osmolarity was adjusted to $340 \mathrm{mmol} / \mathrm{kg}$ with sucrose. Gramicidin perforated whole-cell voltage-clamp recordings were obtained from DRG neurons with capacitances ranging from 15 to $45 \mathrm{pF}$. Patch pipettes with resistances of 2-4 M $\Omega$ were made from borosilicate glass capillaries. The pipette tip was initially filled with gramicidin-free pipette solution by brief immersion, and the remainder of the pipette was back-filled with a $310 \mathrm{mOsm}$ internal solution containing gramicidin plus $140 \mathrm{~mm} \mathrm{CsCl}$ (or $140 \mathrm{~mm} \mathrm{KCl}$, when indicated), $5 \mathrm{~mm}$ EGTA, and $10 \mathrm{~mm}$ HEPES, pH 7.4. A $50 \mathrm{mg} / \mathrm{ml}$ stock solution of gramicidin (Calbiochem, La Jolla, CA) was prepared in dimethylsulfoxide (DMSO; Sigma). Gramicidin was diluted into the pipette solution to a final concentration of $100 \mu \mathrm{g} / \mathrm{ml}$ before use.

The junction potential between the patch pipette and the bath solutions was nulled before the gigaohm seal was formed. After the formation of a tight seal, the progress of gramicidin perforation was evaluated by monitoring the capacitative current transient produced by a $10 \mathrm{msec}$ hyperpolarizing voltage step $(5 \mathrm{mV})$ from the holding potential $(-50 \mathrm{mV})$ every 30 sec. With $100 \mu \mathrm{g} / \mathrm{ml}$ gramicidin in the pipette, the access resistance dropped to $<20 \mathrm{M} \Omega$ within $20 \mathrm{~min}$ after seal formation. GABA and other drugs were applied by gravity-driven perfusion as described previously (Choi and Lovinger, 1996). Drugs were dissolved in external solution and delivered from a linear array of microcapillary tubes $0.32 \mathrm{~mm}$ inne diameter). The tips of the drug application pipettes were placed within 100 $\mu \mathrm{m}$ of the neurons. For pretreatment with bumetanide or high potassium, solutions were delivered continuously over the cells for $10 \mathrm{~min}$ before application of GABA. GABA (100 $\mu \mathrm{M}$ to $1 \mathrm{~mm})$ was applied with the membrane potential held at a series of set values.

The peak amplitude of GABA-activated current was calculated by taking the difference between the current amplitude during the predrug application baseline period and the amplitude at the maximal negativity during drug application. Amplitude measurements were performed by the use of the cursor-based system in the pClamp software. Peak current responses for each voltage were plotted three times, and the data were fit by the use of linear regression analysis. The reversal potential of GABAactivated current $\left(E_{\mathrm{GAB}}\right)$ was extracted from the $x$-intercept value of the fit. All averaged values are expressed as the mean \pm SE. Statistical significance was determined by the use of Student's $t$ test with the criterion set at $p<0.05$. The intracellular $\mathrm{Cl}^{-}$concentration was estimated by solving for $\left[\mathrm{Cl}^{-}\right]_{\mathrm{i}}$ in the Nernst equation: $E_{\mathrm{Cl}}=R T / F \ln \left[\mathrm{Cl}^{-}\right]_{\mathrm{i}} /\left[\mathrm{Cl}^{-}\right]_{0}$ using the measured $E_{\mathrm{GABA}}$ to estimate $E_{\mathrm{Cl}}$, the usual value of $R T / F$, and the $\left[\mathrm{Cl}^{-}\right]_{\mathrm{o}}$ concentration set in the experiment.

Behavioral testing. Subjects were 51 mice $\left(22 \mathrm{NKCC1}^{+/+}, 15\right.$ $\mathrm{NKCC} 1^{+-}$, and $\left.14 \mathrm{NKCC}^{-1-}\right)$. Mice were group-housed, three to five per cage, and separated by gender. Food and water were available ad libitum. The colony room was maintained on a 12:12 hr light/dark cycle, with lights on at 6 A.M. All procedures were approved by the Vanderbilt University Medical Center Institutional Animal Care and Use Committee. For the general neurological screen, a subset of tests from the Irwin Gross Neurological Screen (Irwin, 1968) was performed. First, physical characteristics such as coat color and consistency, skin color, appearance of fur, presence of whiskers, and wounds are examined. Then, the mice are weighed, and their body temperature is measured by the use of a rectal probe. The mice are then placed in an empty cage for $3 \mathrm{~min}$, and the responses to the novel environment, such as wild running, excessive grooming or freezing, abnormal gait or postures, piloerection, palpebral closure, tail elevation, urination, and defecation, are observed and noted. For touch sensitivity, mice are stroked with a finger from above, starting light and getting firmer, and the intensity at which mice try to escape is recorded. Then, whisker, righting, reaching, and corneal reflexes are examined. Abdominal and limb tone, as well as pupillary contraction and responses to tail pinch and toe pinch, is also recorded. The Irwin test battery consists of assessments of body temperature and spontaneous behavior in a novel environment, as well as gross measures of vision, hearing, and nociception. Reflexes such as righting, touch escape, trunk curl, reaching, vibrissal, and corneal were also assessed.

The ability to maintain balance on a rotating cylinder was measured with a standard rotorod apparatus (model 7650; Ugo Basile, Varese, Italy). The cylinder was $3.2 \mathrm{~cm}$ in diameter and was covered with scored plastic. Mice were confined to a section of the cylinder $6.0 \mathrm{~cm}$ long by gray Plexiglas dividers. Each mouse was placed on the cylinder, which increased rotation speed over a $5 \mathrm{~min}$ period from 4 to $40 \mathrm{rpm}$. The latency at which the mouse fell off the rotating cylinder was measured. Mice that fell in $<15 \mathrm{sec}$ were given a second trial. Mice that did not fall during the $300 \mathrm{sec}$ trial period were removed and given a score of $300 \mathrm{sec}$. Mice were tested three times daily for $3 \mathrm{~d}$.

For nociception threshold measurement, each mouse was placed on a hot plate maintained at $52^{\circ} \mathrm{C}$ (model 35D; IITC Corporation, Woodland Hills, CA). A plastic cylinder $15 \mathrm{~cm}$ in diameter and $12.5 \mathrm{~cm}$ high confined the mouse to the surface of the hot plate. The time it took the mouse to jump or lick its paw was measured with a stop watch. Mice were then immediately removed from the hot plate. Because NKCC1 knock-out mice are spastic and may not be able to lick their paws as deftly as wild-type mice, changes in other behaviors thought to be indicative of a nociceptive response were also recorded. Shaking or lifting paws, increasing motor activity, and jumping were all considered responses to the thermal stimulus for all three genotypes.

Analyses of the independence of observations of the hot plate behaviors were performed using $\chi^{2}$ and Cramer's $\phi$, a transformation of $\chi^{2}$ that results in a coefficient ranging from 0 to 1 representing the strength of association (Welkowitz et al., 1982). Hot plate latencies were analyzed by the use of ANOVA. Planned follow-up comparisons were conducted with Fisher's protected least significant difference (PLSD) statistic after a significant omnibus $F$ ratio. Analysis of rotorod data was conducted by the use of repeated-measures ANOVA (RMANOVA). Follow-up analyses of rotorod data were made with two-group RMANOVA. Degrees of freedom for RMANOVAs were adjusted for sphericity by the use of the Greenhouse-Geisser $\epsilon$.

\section{RESULTS}

Gramicidin perforated-patch (PP) recordings were successfully performed in a total of $48 \mathrm{DRG}$ neurons isolated from 15 wild-type mice and 48 neurons isolated from 9 homozygote NKCC1 knockout mice. The whole-cell capacitance of these neurons ranged from 13.2 to $57 \mathrm{pF}$, with several neurons from both wild-type and $\mathrm{NKCC} 1^{-1-}$ mice having capacitances in the 15-20, 20-30, and $30-50 \mathrm{pF}$ ranges, indicating that the cells we examined spanned the entire range of sizes of primary sensory neurons. There was no significant difference in the whole-cell capacitances when comparing the wild-type and $\mathrm{NKCC1}^{-/-}$mice [average capacitance $=$ $29.5 \pm 1.1 \mathrm{pF}$ for wild-type mouse neurons $(n=39)$ and $26.9 \pm 1.5$ $\mathrm{pF}$ for $\mathrm{NKCC} 1^{-/-}$mice $(n=39) ; p=0.15$, unpaired $t$ test].

Application of $1 \mathrm{~mm}$ GABA to the neurons during recordings from wild-type mice elicited inward current when the membrane potential was voltage-clamped at $-50 \mathrm{mV}$ in the large majority of cells (Fig. 1A). Inward current was also observed after GABA application at $-30 \mathrm{mV}$, but current reversed to an outward direction when the membrane potential was clamped at $-10 \mathrm{mV}$ in all DRG neurons tested (Fig. $1 A$ ). When $10 \mu \mathrm{M}$ bumetanide was applied before and during GABA application, outward current was elicited after GABA exposure at $-30 \mathrm{mV}$ (Fig. $1 B$ ). Similar reversal potentials and effects of bumetanide were observed in 12 neurons from eight wild-type mice.

Subsequent to completion of recordings in the PP mode, we applied additional negative pressure to the recording pipette to 

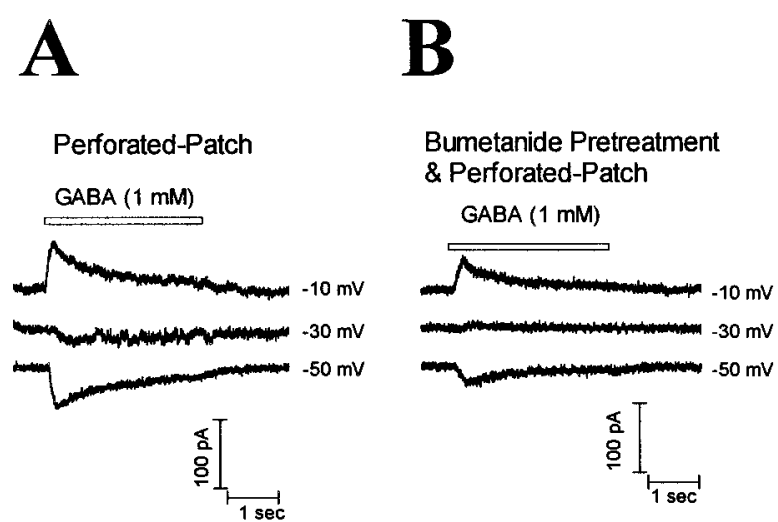

\section{Whole Cell Patch}

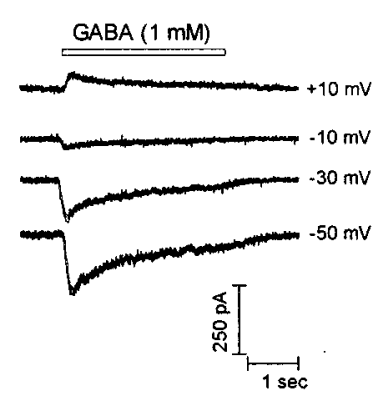

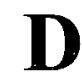
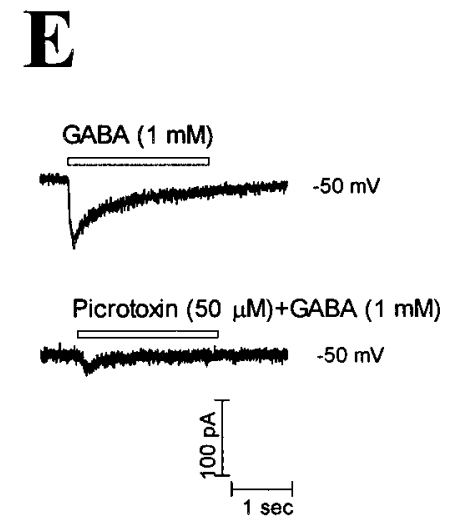

Figure 1. Bumetanide sensitivity of $\mathrm{GABA}_{\mathrm{A}}$ receptor-mediated current in mouse DRG neurons. $A$, Current activated by GABA application to an isolated DRG neuron from a wild-type mouse during gramicidin PP recording. $B$, Recording from the same neuron shown in $A$ after a $10 \mathrm{~min}$ application of $10 \mu \mathrm{M}$ bumetanide. $C$, Recording from the same neuron beginning $5 \mathrm{~min}$ after initiation of whole-cell recording after completion of the PP recording. $D$, Current-voltage relationship for GABA-activated responses under the three recording conditions shown in $A-C$. Note the hyperpolarizing shift in $E_{\mathrm{GABA}}$ in the presence of bumetanide and the shift of $E_{\mathrm{GABA}}$ to near $0 \mathrm{mV}$ during whole-cell recording. $E$, Current activated by GABA in a second neuron in the absence (top) and presence (bottom) of picrotoxin during gramicidin $\mathrm{PP}$ recording. The strong inhibition of the response by picrotoxin indicates that the current is $\mathrm{GABA}_{\mathrm{A}}$ receptor-mediated. rupture the cell membrane for whole-cell recording in the same DRG neurons. The intracellular solution contained a high $\mathrm{CsCl}$ concentration $(140 \mathrm{~mm})$. We allowed at least $5 \mathrm{~min}$ after rupture of the membrane before initiating GABA application in these wholecell recordings to allow the high $\mathrm{CsCl}$-containing solution to permeate the cell. We obtained successful whole-cell recordings in nine neurons in this experiment, and GABA-activated current was inward at all negative membrane potentials and outward at positive membrane potentials (Fig. $1 C$ ). Figure $1 D$ presents the currentvoltage $(I / V)$ relationship for responses to $1 \mathrm{~mm}$ GABA under PP and whole-cell recording conditions for the recordings from the same neuron that generated the responses shown in Figure $1 A-C$. It can be seen that the reversal potential for GABA-activated current is shifted to a slightly more negative value in the presence of bumetanide relative to that in the bumetanide-free condition (control $=-31.3 \pm 3 \mathrm{mV}$; bumetanide $=-37.2 \pm 2.9 \mathrm{mV} ; n=12$ cells per group; $p<0.05$, unpaired $t$ test). However, it should be noted that the amplitude of GABA-activated current was reduced in the presence of bumetanide even at membrane potentials at which the current should be larger (e.g., $-10 \mathrm{mV}$ ) if the only effect of the drug was to alter the reversal potential for the GABA-gated channel. This decrease in the amplitude of GABA-activated current at all membrane potentials reflects a change in the whole-cell $\mathrm{GABA}_{\mathrm{A}}$ receptor-channel conductance (Fig. 2). Similar direct effects on $\mathrm{GABA}_{\mathrm{A}}$ receptor function have been observed previously in the presence of high concentrations of the loop diuretic furosemide (Nicoll, 1978; Inomata et al., 1988; Pearce, 1993; Korpi and Luddens, 1997). It can also be seen that the reversal potential moved to $\sim 0 \mathrm{mV}$ during whole-cell recording in this cell. The reversal potential for GABA-activated current averaged $-31.3 \pm 3$ $\mathrm{mV}(n=12)$ during gramicidin PP recordings, $-37.2 \pm 3 \mathrm{mV}(n=$ 12) during gramicidin PP recordings in the presence of bumetanide, and $0.6 \pm 3 \mathrm{mV}(n=9)$ during whole-cell recordings in a subset of this group of neurons.

When $100 \mu \mathrm{M}$ picrotoxin was applied before and during GABA application in gramicidin PP experiments, a large reduction in the amplitude of GABA-gated current was observed (Fig. 1E). Similar

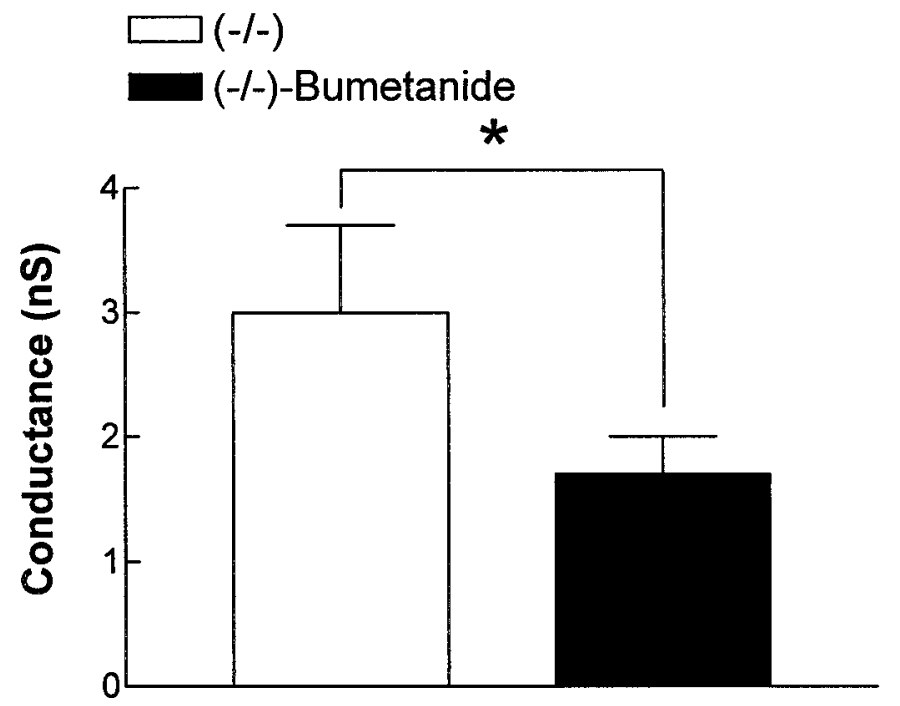

Figure 2. Bumetanide inhibition of $\mathrm{GABA}_{\mathrm{A}}$ receptor function. Plot of GABA-activated whole-cell conductance before bumetanide treatment (left) and after $2 \mathrm{~min}$ of exposure to $10 \mu \mathrm{M}$ bumetanide (right; $n=12$ per group). The asterisk indicates a significant decrease ( $p<0.05$, paired $t$ test $)$.

results were observed in five neurons, and the average reduction in current amplitude in the presence of $50-100 \mu \mathrm{M}$ picrotoxin was $65 \pm 11 \%$. Picrotoxin alone did not elicit any current.

The observation that bumetanide and other loop diuretics have direct actions on $\mathrm{GABA}_{\mathrm{A}}$ receptors raises some concern about the interpretation of experimental results generated with these reagents. Furthermore, these inhibitors only selectively block $\mathrm{Na}-\mathrm{K}-$ $2 \mathrm{Cl}$ cotransport over a limited concentration range and may have actions on other $\mathrm{Cl}^{-}$transporters at drug concentrations that are required to block the cotransporter completely (Russell, 2000). Thus, it is important to use alternative experimental approaches to 


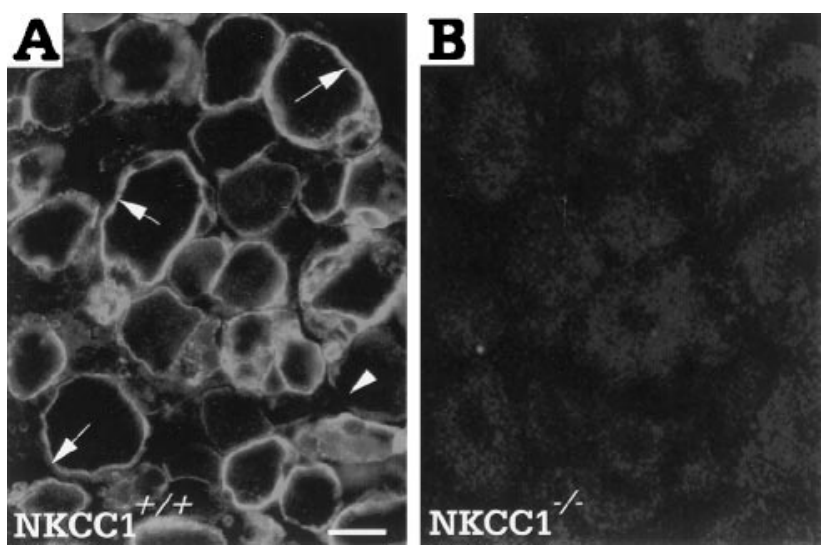

Figure 3. Immunofluorescence staining shows the absence of $\mathrm{Na}-\mathrm{K}-2 \mathrm{Cl}$ cotransporter expression in DRG neurons from homozygote mutant mice. The rabbit polyclonal antibody is directed against a 74 amino acid peptide located in the C terminal of NKCC1 (Kaplan et al., 1996). A, Control mouse DRG neurons highly express the NKCC1 protein. The signal is predominantly located at the cell membrane (arrows). Note the presence of a few neurons with a minimal amount of cotransporter expression (arrowhead). $B$, Identical view of DRG neurons from a homozygote mutant animal demonstrates the complete absence of NKCC1 expression. Scale bar, $20 \mu \mathrm{m}$.

determine the role of the $\mathrm{Na}-\mathrm{K}-2 \mathrm{Cl}$ cotransporter in setting the $\mathrm{Cl}^{-}$equilibrium potential in neurons.

An experimental approach that would provide a strong test of the hypothesis that the cotransporter plays a role in setting the transmembrane $\mathrm{Cl}^{-}$gradient in DRG neurons would be to remove expression of the transporter altogether. This was accomplished by disrupting the cotransporter gene and thus generating the $\mathrm{NKCC1}$ knock-out mouse (Delpire et al., 1999). Using a rabbit polyclonal antibody directed against a specific C-terminal epitope of the cotransporter (Kaplan et al., 1996), we demonstrated high expression levels of the cotransporter in wild-type DRG neurons (Fig. $3 A$ ) and confirmed the absence of cotransporter expression in the NKCC1 homozygote mutants (Fig. 3B).

We then performed gramicidin perforated-patch recording experiments in DRG neurons isolated from wild-type and NKCC1 knock-out mice. We first wanted to determine whether the depolarizing effect of GABA normally observed in DRG neurons would be impaired in the NKCC1 knock-out mouse neurons. Using our standard $\mathrm{CsCl} /$ gramicidin $\mathrm{PP}$ recording conditions, we observed that $E_{\mathrm{GABA}}$ was consistently more depolarized in DRG neurons from wild-type compared with neurons from NKCC1 knock-out mice. Figure 4 illustrates representative current traces (Fig. 4A,B) and representative current-voltage $(I / V)$ relationships (Fig. $4 C$ ) for GABA-activated current in wild-type and NKCC1 knock-out mouse DRG neurons. When recording under our initial gramicidin PP conditions (5 $\mathrm{mm}[\mathrm{K}]_{\mathrm{o}}$ and Cs-based internal solution), the reversal potential averaged $-37 \pm 2.7 \mathrm{mV}$ in wild-type mouse neurons $(n=35$ cells $)$ and $-53 \pm 2 \mathrm{mV}$ in N KCC1 knock-out mice $\left(n=39\right.$ cells), which correspond to intracellular $\mathrm{Cl}^{-}$concentrations of $46 \pm 4$ and $24 \pm 2 \mathrm{~mm}$, respectively. Whole-cell capacitance and $E_{\mathrm{GABA}}$ were not significantly correlated in neurons from either wild-type or $\mathrm{NKCC1}^{-1-}$ mice. We also measured the reversal potential of GABA-activated current during whole-cell recordings performed subsequent to completing gramicidin PP recordings in the wild-type and knock-out mouse neurons. Reversal potentials were near $0 \mathrm{mV}$ for neurons from both groups of mice, and no significant difference between the two groups was observed [wild type $=2 \pm 1.3 \mathrm{mV}(n=24) ;$ knock-out $=-1 \pm 1.3 \mathrm{mV}(n=26)$; $p=0.082$, unpaired $t$ test]. This finding supports the idea that the difference in reversal potentials observed under the gramicidin PP condition was caused by a difference in the transmembrane $\mathrm{Cl}$ gradient and not caused by a difference in the ion permeability of the $\mathrm{GABA}_{\mathrm{A}}$ receptor-linked channel. The density of GABAactivated current in NKCC1 knock-out mouse neurons was similar to that measured in neurons from wild-type mice $[8.01+1.16$ $\mathrm{pA} / \mathrm{pF}(n=26$ cells, 9 mice $)$ for homozygote vs $10.22+1.49 \mathrm{pA} / \mathrm{pF}$ $(n=26$ cells, 12 mice) for wild type; $p>0.2, t$ test, NS). Furthermore, the whole-cell GABA-activated conductance was similar in wild-type and knock-out mice $[2.9 \pm 0.83 \mathrm{nS}(n=12)$ vs $2.98 \pm$ $0.67 \mathrm{nS}(n=11) ; p=0.93$, unpaired $t$ test]. Thus, elimination of the transporter does not appear to have altered expression or function of $\mathrm{GABA}_{\mathrm{A}}$ receptor channels.

To determine whether application of GABA would produce depolarization or hyperpolarization at the resting membrane potential, we recorded the resting potential ( 0 current level) just after the initiation of $\mathrm{PP}$ recordings using a $\mathrm{KCl}$-based intracellular solution (see Materials and Methods). We then voltage-clamped the membrane potential at the level of the measured resting potential and applied $1 \mathrm{~mm}$ GABA to activate the receptors. Application of GABA at the resting potential in DRG neurons from wild-type mice produced a substantial inward current, whereas GABA application at the resting membrane potential in DRG neurons from NKCC1 knock-out mice produced little or no net current flow, on average. We observed inward current at the resting potential in all of the six neurons from wild-type mice, but neurons from NKCC1 knock-out mice exhibited small-amplitude inward current at the resting potential in four of the six neurons examined, whereas the two remaining neurons responded to GABA with outward current. We determined the reversal potential for GABAinduced current in these neurons and compared this value with the resting membrane potential measured in the same neurons. These data are summarized in Figure $4 D$. This figure plots the difference between $E_{\mathrm{GABA}}$ and the resting membrane potential (RMP) with the resting membrane potential for each cell shown on the $x$-axis. It can be seen from this graph that $E_{\mathrm{GABA}}$ was considerably positive to the RMP in almost all of the neurons from wild-type mice, whereas $E_{\mathrm{GABA}}$ was observed at membrane potentials either slightly depolarized or slightly hyperpolarized relative to the RMP in NKCC1 knock-out mouse neurons. The averaged values for all of these neurons are shown in Figure $4 D$, inset. This figure also shows that the RMP values for the different neurons did not differ systematically between wild-type and NKCC1 knock-out mouse neurons. The average resting membrane potential did not differ significantly in knock-out mouse neurons in comparison with wildtype mouse neurons [RMP $=-68 \pm 2 \mathrm{mV}$ in wild-type mouse cells $(n=6)$ and $-62 \pm 3.3 \mathrm{mV}$ in cells lacking NKCC1 $(n=6)$; $p=0.144$, unpaired $t$ test].

Elimination of NKCC1 expression should eliminate the bumetanide-induced hyperpolarizing shift in $E_{\mathrm{GABA}}$ by eliminating the major diuretic-sensitive mechanism for $\mathrm{Cl}^{-}$accumulation in the neuron. Thus, we examined the effect of application of $10 \mu \mathrm{M}$ bumetanide on current activated by GABA and the reversal potential of this current in DRG neurons from wild-type and N KCC1 mice. Figure $5 A$ shows that the reversal potential for GABA-gated $\mathrm{Cl}^{-}$current was actually shifted to a more depolarized potential during bumetanide application to DRG neurons from $\mathrm{NKCC} 1$ knock-out mice (control $=-55.5 \pm 3.7 \mathrm{mV}$; bumetanide $=-47 \pm$ $2.5 \mathrm{mV} ; p<0.05$, unpaired $t$ test). This is the opposite of what is observed in neurons from wild-type mice as shown in Figures 1 and $5 A$. Thus, a bumetanide-sensitive mechanism for decreasing intracellular $\mathrm{Cl}^{-}$likely exists in DRG neurons. This mechanism is normally overshadowed by the activity of the $\mathrm{Na}-\mathrm{K}-2 \mathrm{Cl}$ cotransporter but is unmasked when the inward cotransport mechanism is removed. The decrease in the GABA-activated conductance in the presence of bumetanide was observed even in the NKCC1 knockout mouse neurons $[2.98 \pm 0.67 \mathrm{nS}(n=11)$ for untreated knockout cells and $1.67 \pm 0.33 \mathrm{nS}(n=11)$ for bumetanide-treated knock-out cells; $p<0.05$ ], and this decrease was similar in magnitude to that observed in wild-type mice. This observation further supports a direct effect of the diuretic on the $\mathrm{GABA}_{\mathrm{A}}$ receptor complex.

Because cation $-\mathrm{Cl}^{-}$cotransporters are sensitive to extracellular cation concentrations, we examined the effect of altering extracellular $\mathrm{K}^{+}$on the reversal potential of GABA-activated current to 


\section{A $\quad$ B}

NKCC1 (+/+)
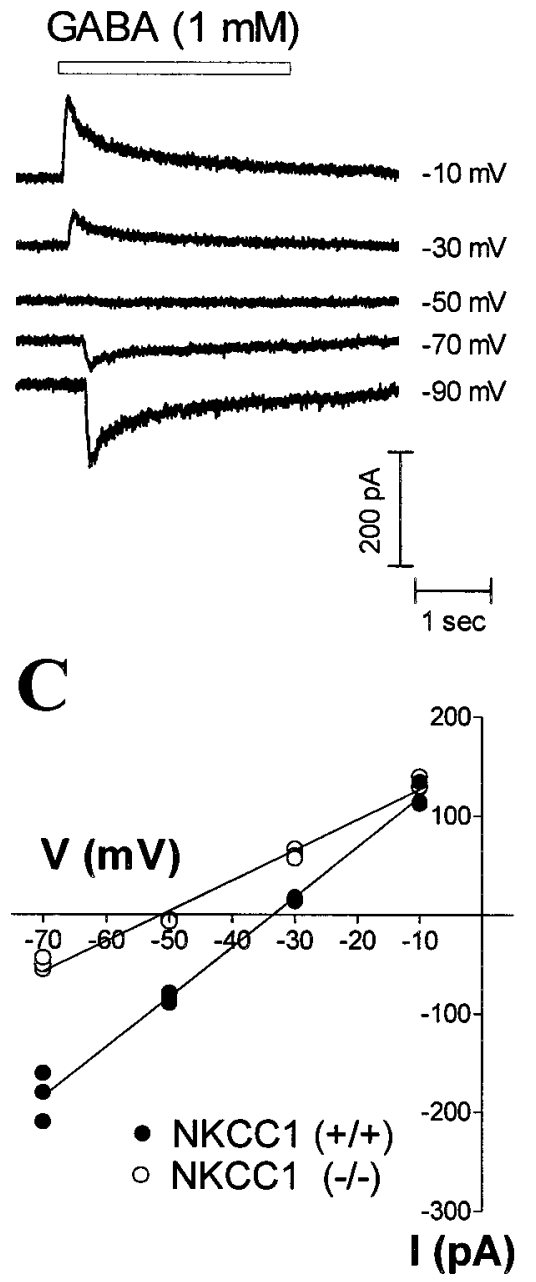

NKCC1 (-/-)
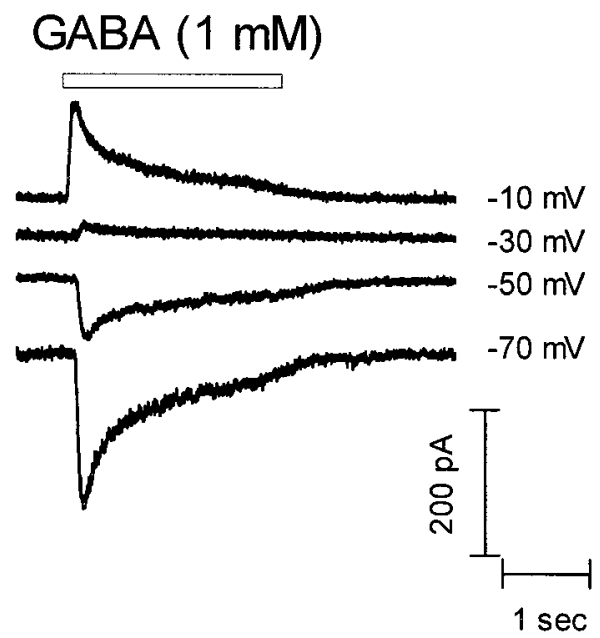

D

$1 \mathrm{sec}$

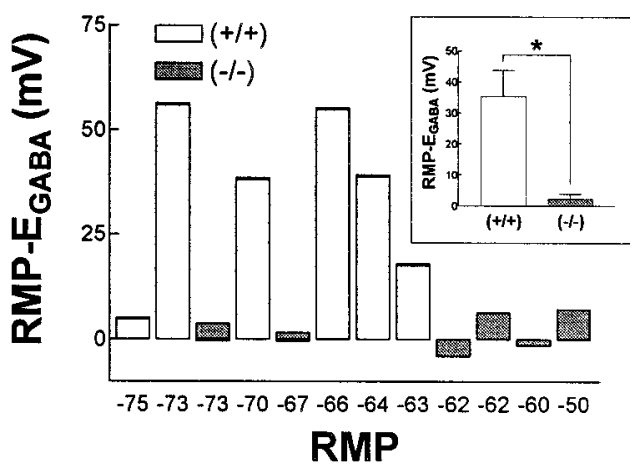

Figure 4. Knock-out of the NKCC1 gene produces a hyperpolarizing shift in $E_{\mathrm{GABA}} A, B$, Current activated by GABA in a single wild-type mouse neuron $(A)$ and a single NKCC1 knock-out mouse neuron $(B)$. Note that the current reverses polarity at approximately $-35 \mathrm{mV}$ in the wild-type mouse neuron but at approximately $-50 \mathrm{mV}$ in the NKCC1 knock-out mouse cell. $C$, Current-voltage relationship for GABA-activated current in single Cs-filled wild-type and NKCC1 knock-out mouse neurons. Peak current amplitudes were calculated from the traces in $A$ and $B$. Note that $E_{\mathrm{GABA}}$ is at a more depolarized value in the wild-type mouse neuron than in the knock-out mouse neuron. $D$, Data for six neurons from wildtype and six from NKCC1 knock-out mice recorded with a potassium-based intracellular solution. This graph shows the difference between the RMP and the reversal potential of GABA-activated current $\left(E_{\mathrm{GABA}}\right)$, as well as the RMP, for each neuron. Positive values indicate that $E_{\mathrm{GABA}}$ is depolarized relative to the RMP, whereas negative values indicate that $E_{\mathrm{GABA}}$ is hyperpolarized relative to rest. Inset, A plot of the mean \pm SEM values for all of the wild-type and NKCC1 knock-out neurons. Note that $E_{\mathrm{GABA}}$ is more depolarized in wild-type than in NKCC1 knock-out mouse neurons. The asterisk indicates a significant decrease $(p<0.05$, paired $t$ test). determine whether this manipulation produced a differential effect in wild-type versus NKCC1 knock-out mice. We observed that increasing the $\mathrm{K}^{+}$concentration from 5 to $10 \mathrm{~mm}$ caused a shift in $E_{\mathrm{GABA}}$ to more depolarized potentials that was approximately equivalent in both wild-type and knock-out mouse DRG neurons (Figure $5 B$ ). This finding indicates that a $\mathrm{K}$-sensitive transporter is acting to lower $E_{\mathrm{Cl}}$ in the absence or presence of NKCC1. This observation also supports the idea that DRG neurons contain cation- $\mathrm{Cl}^{-}$cotransporters other than NKCC1.

We also lowered the extracellular $\mathrm{Cl}^{-}$concentration by reducing the $\mathrm{NaCl}$ concentration in our extracellular solution from 150 to $100 \mathrm{~mm}$, substituting the remaining $50 \mathrm{~mm}$ with Na-gluconate. This treatment should reduce the inward transport mediated by $\mathrm{NKCC} 1$ and result in a reduction in intracellular $\mathrm{Cl}^{-}$concentration. The $E_{\mathrm{GABA}}$ values were shifted to slightly more depolarized values in both the wild-type and NKCC1 knock-out mouse neurons (from $-34 \pm 2$ to $-29 \pm 2 \mathrm{mV}$ in wild-type neurons and from $-52 \pm 5$ to $-45 \pm 5 \mathrm{mV}$ in $\mathrm{NKCC1}$ knock-out neurons) after reducing $\left[\mathrm{Cl}^{-}\right]_{\mathrm{o}}$. In both sets of mice these shifts in $E_{\mathrm{GABA}}$ were statistically significant ( $p<0.05$, repeated measures $t$ test). This is to be expected because of the change in $\mathrm{Cl}^{-}$-driving force produced by this treatment. Using these measured $E_{\mathrm{GABA}}$ values, we were then able to calculate the $\left[\mathrm{Cl}^{-}\right]_{\mathrm{i}}$ value by the use of the Nernst equation (see Materials and Methods). Figure $5 C$ shows that the reduction in $\left[\mathrm{Cl}^{-}\right]_{\mathrm{o}}$ produced a significant decrease in $\left[\mathrm{Cl}^{-}\right]_{\mathrm{i}}$ in DRG neurons from wild-type but not knock-out mice $(p<0.05$ for wild-type data, $p>0.2$ for $\mathrm{NKCC} 1$ knock-out data, repeated measures $t$ test). This finding is consistent with the idea that the intracellular $\mathrm{Cl}^{-}$ concentration in DRG neurons is sensitive to $\left[\mathrm{Cl}^{-}\right]_{\mathrm{o}}$ only when NKCC1 is present. Figure $5 C$ also shows that $\left[\mathrm{Cl}^{-}\right]_{\mathrm{i}}$ was lower in the NKCC1 knock-out mouse neurons in comparison with wildtype mouse neurons under both the normal and reduced $\left[\mathrm{Cl}^{-}\right]_{\mathrm{o}}$ conditions, consistent with the outcome of previous experiments indicating that loss of $\mathrm{NKCC} 1$ reduces the $\mathrm{Cl}^{-}$concentration in DRG neurons. As expected, $\left[\mathrm{Cl}^{-}\right]_{\mathrm{i}}$ measured during whole-cell recording in the reduced $\left[\mathrm{Cl}^{-}\right]_{\mathrm{o}}$ condition did not differ in wildtype compared with knock-out mouse neurons (data not shown).

To relate these abnormal GABAergic responses in DRG neurons to proprioception, we subjected the mice to a series of behavioral tests, starting with a gross behavioral analysis. To assess gross neurological function in the knock-out mice, a subset of tests from the Irwin (1968) screen was performed. The Irwin screen is a comprehensive set of assessment tools for detecting neurological and behavioral abnormalities in mice. The Irwin screen is the standard basic test battery used to control for procedural abilities (e.g., walking) required in more complex behavioral tests (e.g., memory) in both behavioral pharmacology and behavioral genetics (Irwin, 1968; Banfi et al., 1982; Hunter et al., 2000). The Irwin screen has been incorporated into or is the basis for a number of alternate behavioral test batteries (Crawley and Paylor, 1997; Rogers et al., 1997). Perhaps the most salient behavior observed during the gross neurological screen was the spontaneous retropulsive 
Figure 5. Pharmacological properties and ion sensitivity of the reversal potential of GABA-gated current in wild-type and NKCC1 knock-out mouse DRG neurons. $A$, Plot of the change in $E_{\mathrm{GABA}}$ during exposure to bumetanide in the wild-type and knock-out mouse neurons ( $n=12$ wild-type mouse neurons and 11 knock-out mouse neurons). Note the opposite effects of bumetanide in the two sets of neurons. $B$, Plot of the change in $E_{\mathrm{GABA}}$ after exposure to increased $\left[\mathrm{K}^{+}\right]_{\mathrm{o}}$ in wild-type and knock-out mouse neurons $(n=$ 6 wild-type mouse neurons and 8 knock-out mouse neurons). $C$, Plot of the change in $\left[\mathrm{Cl}^{-}\right]_{\mathrm{i}}$ after exposure to low $\left[\mathrm{Cl}^{-}\right]_{\mathrm{o}}$ in the wild-type and NKCC1 knock-out mouse neurons $(n=9$ wild-type mouse neurons and 6 knock-out mouse neurons). Intracellular $\mathrm{Cl}^{-}$was estimated by the use of $E_{\mathrm{GABA}}$ and the known $\left[\mathrm{Cl}^{-}\right]_{\mathrm{o}}$ as described in the text. Single and double asterisks refer to $p<0.05$ and $p<0.005$, respectively.
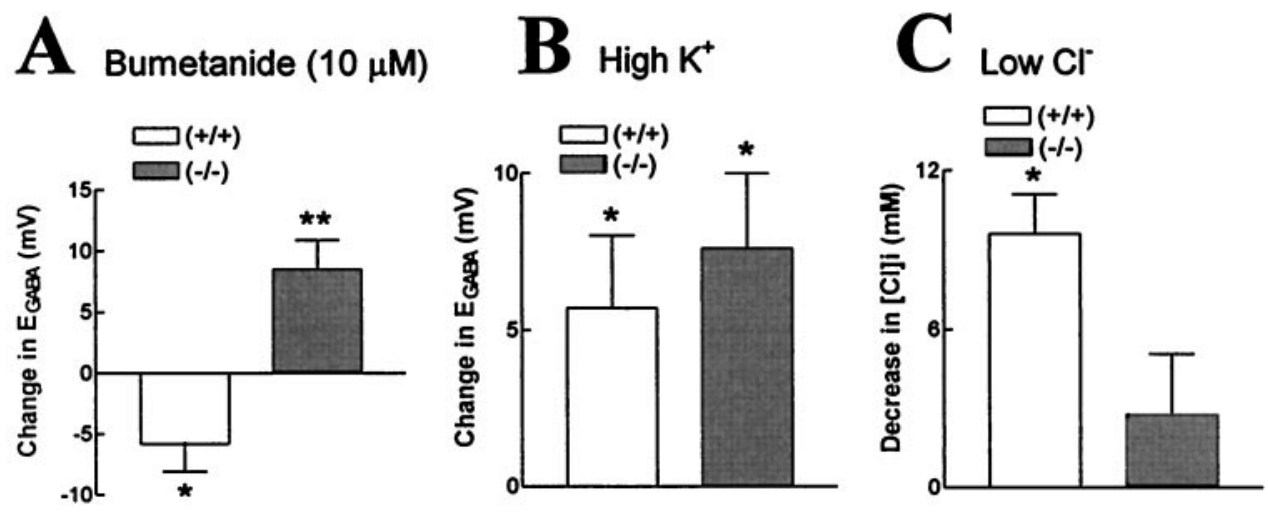

response to a novel environment on the part of the knock-out mice. In this test, mice were placed in a clean mouse tub cage and observed for a period of $3 \mathrm{~min}$. Retropulsion was immediate after placement into the tub cage and was characterized by rapidly walking backward until reaching the edge of the cage and continuing until the rear legs were propped up on the side of the cage. The mice then maintained a vertical, head-down position, although spastic movements continued. After a short period in this vertical position, knock-out mice began moving again and exploring the rest of the cage. In addition to this behavior, knock-out mice appeared to struggle more when touched or restrained and when held aloft by the tail, although this may be a manifestation of their spasticity. Other behaviors assessed during the gross neurological screen were normal, including all reflexes tested, toe and tail pinch, and muscle tone.

The rotorod performance of the knock-out mice was severely impaired $\left[F_{(2,48)}=53.0 ; p<0.0001\right]$, as depicted in Figure 6 . Follow-up analyses demonstrate that the knock-out mice fell off the rotorod much sooner than did both the wild-type $\left[F_{(1,34)}=101.9\right.$; $p<0.0001]$ and heterozygous $\left[F_{(1,27)}=92.5 ; p<0.0001\right]$ mice. Interestingly, the rotorod performance of the knock-out mice improved significantly over the nine testing sessions $[\epsilon=0.282$; $F_{(2,29)}=3.3 ; p=.0023$ ], increasing from a mean of $15-18 \mathrm{sec}$ on day 1 to $30-39 \mathrm{sec}$ on day 3 . This demonstrates that the knock-out mice retain some ability to learn motor skills in spite of their debilitating spasticity. The rotorod performance of wild-type and heterozygous mice did not differ significantly $\left[F_{(1,35)}=1.0\right.$; $p=0.335]$.

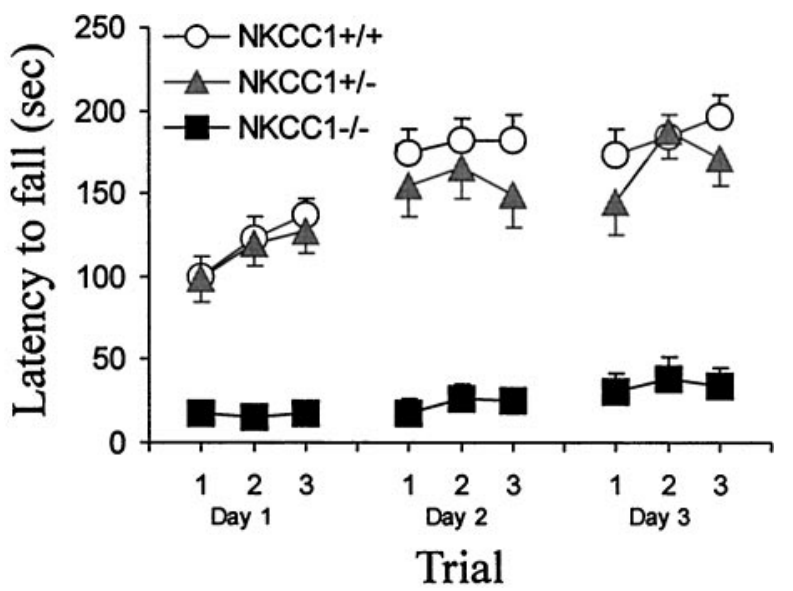

Figure 6. Performance on the rotorod test of motor coordination. Mice were placed on an accelerating rotorod for three trials per day for $3 \mathrm{~d}$. The latency to fall off the rotorod was assessed. NKCC1 ${ }^{-1-}$ mice had significantly impaired motor coordination compared with that of wild-type or $\mathrm{NKCC1}$ heterozygous mice. Data represent the mean $\pm \mathrm{SEM}$.
The types of behavior that the mice exhibited in response to pain differed significantly across genotype $\left(\mathrm{df}=6 ; \chi^{2}=25.1 ; \phi=0.646\right.$; $p=0.0003)$. Wild-type $\left(\mathrm{df}=1 ; \chi^{2}=11.8 ; \phi=0.789 ; p=0.0006\right)$ and heterozygous ( $\left.\mathrm{df}=1 ; \chi^{2}=12.7 ; \phi=0.798 ; p=0.0004\right)$ mice were more likely to exhibit guarding behavior (lifting or shaking the paw), whereas the knock-out mice were more likely to increase locomotor activity in response to the thermal stimulus. There was no significant difference across genotypes in the proportion of mice that exhibited alternate behavior (i.e., other than licking) after being placed on the hot plate $\left(\mathrm{df}=2 ; \chi^{2}=2.6 ; \phi=0.226 ; p=\right.$ 0.278 ) or in the topography of nociceptive responding between wild-type and heterozygous mice $\left(\mathrm{df}=2 ; \chi^{2}=0.9 ; \phi=0.2 ; p=\right.$ $0.645)$.

Knock-out mice exhibited impaired pain perception on the hot plate, as demonstrated by longer response latencies [Fig. 7; $\left.F_{(2,43)}=4.3 ; p=0.0196\right]$. Follow-up analyses showed that the knock-out mice were significantly less sensitive to the thermal stimulus compared with both the wild-type $(\mathrm{PLSD}=4.72 ; p=$ $0.0054)$ and heterozygous (PLSD $=5.02 ; p=0.0466)$ groups. The mean response latency of the heterozygous mice did not differ from that of the wild-type mice (PLSD $=4.16 ; p=0.3974$ ). Four knock-out mice were excluded from the analysis of hot plate latencies because they exhibited spontaneous retropulsion after being placed on the hot plate. Because this retropulsive response was immediate and occurred long before the typical latencies of other nociceptive responses in any of the mice, it was impossible to distinguish whether the retropulsion was in response to the thermal stimulus or in response to a novel environment, as observed in the gross neurological screen.

In spite of differences in behaviors in response to the thermal stimulus, all but five mice (three wild types and two knock-outs) also licked their paws when exposed to the high temperature, including two of the four knock-out mice that retropulsed and whose rear paws were in contact with the acrylic restraining wall and not with the hot plate. When only latency to lick was consid-

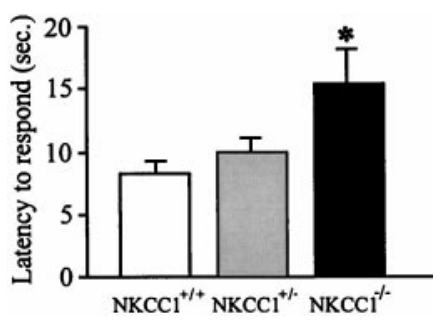

Figure 7. Performance on the hot plate test of nociception. Mice were placed on the hot plate at a temperature of $52^{\circ} \mathrm{C}$. The latency to lick a paw or to emit another pain-associated behavior was assessed. NKCC1 mice were significantly (asterisk, $p<0.05$ ) less sensitive to the thermal stimulus than were wild-type or $\mathrm{NKCC1}^{+/-}$heterozygous mice. Data represent the mean $\pm \mathrm{SEM}$. 
ered, knock-out mice were still significantly impaired relative to wild-type and heterozygous mice $\left[F_{(2,43)}=5.9 ; p=0.0054\right]$.

\section{DISCUSSION}

Removal of $\mathrm{NKCC} 1$ reduces $\left[\mathrm{Cl}^{-}\right]_{\mathrm{i}}$ in mouse DRG neurons (Fig. 4), supporting the idea that this cotransporter plays a major role in determining the transmembrane $\mathrm{Cl}^{-}$concentration gradient in these cells. The experiments involving bumetanide application and manipulation of ion concentrations further support this idea. The predominant effect of bumetanide in wild-type DRG neurons is to shift $E_{\mathrm{GABA}}$ to more hyperpolarized potentials, indicating a decrease in $\left[\mathrm{Cl}^{-}\right]_{\mathrm{i}}$. In addition, reducing $\left[\mathrm{Cl}^{-}\right]_{\mathrm{o}}$ reduces $\left[\mathrm{Cl}^{-}\right]_{\mathrm{i}}$ in wild-type neurons, consistent with a reduction in activity of an inward $\mathrm{Cl}^{-}$transporter such as $\mathrm{NKCC1}$. Both of these effects are lost in the NKCC1 knock-out mouse, strongly implicating this transporter in concentrating $\mathrm{Cl}^{-}$inside mouse DRG neurons under normal conditions. These data are consistent with those obtained from frog dorsal root ganglion neurons by the use of ionselective microelectrodes or from Amphiuma Rohon-Beard spinal neurons by the use of the gramicidin perforated-patch method, which clearly indicated accumulation of $\mathrm{Cl}^{-}$via a bumetanidesensitive, $\mathrm{Na}^{+}-$and $\mathrm{K}^{+}$-dependent $\mathrm{Na}-\mathrm{K}-2 \mathrm{Cl}$ cotransporter (Alvarez-Leefmans et al., 1988; Rohrbough and Spitzer, 1996)

Our findings also suggest that another transporter, in addition to $\mathrm{NKCC} 1$, regulates intracellular $\mathrm{Cl}^{-}$concentration in mouse DRG neurons. We observed a bumetanide-induced depolarizing shift in $E_{\mathrm{GABA}}$ in the NKCC1 knock-out mouse neurons that was not observed in neurons from wild-type animals. This suggests that bumetanide inhibits a transporter, other than $\mathrm{NKCC} 1$, that mediates $\mathrm{Cl}^{-}$extrusion from these neurons. Further support for involvement of another transporter comes from the observation that altering $\left[\mathrm{K}^{+}\right]_{\mathrm{o}}$ alters $E_{\mathrm{GABA}}$, and thus $\left[\mathrm{Cl}^{-}\right]_{\mathrm{i}}$, to a similar extent in both wild-type and knock-out mouse neurons. One likely candidate transporter that could mediate this action is a $\mathrm{K}-\mathrm{Cl}$ cotransporter. Indeed, the effect of increasing $\left[\mathrm{K}^{+}\right]_{\mathrm{o}}$ is consistent with a role for this transporter because this treatment would be expected to increase $\left[\mathrm{Cl}^{-}\right]_{\mathrm{i}}$ if this transporter is present, and our results indicate that such an increase actually takes place. Four isoforms of the $\mathrm{K}-\mathrm{Cl}$ cotransporter have been cloned with one, $\mathrm{KCC} 2$, being expressed exclusively in neurons. Using PCR and immunofluorescence, we have demonstrated previously the presence of KCC2 in DRG neurons (Lu et al., 1999). Other isoforms of the $\mathrm{K}-\mathrm{Cl}$ cotransporter might also be expressed in these cells. This $\mathrm{K}-\mathrm{Cl}$ cotransporter may function in wild-type DRG, and its action would tend to oppose that of NKCC1.

Interestingly, Ehrlich et al. (1999) have observed a positive shift in $E_{\text {glycine }}$ induced by furosemide in postnatal day 8 (P8)-P10 lateral superior olive neurons, instead of the negative shift observed in younger P2-P4 neurons. The positive shift in mature neurons suggests inhibition of a net outward $\mathrm{Cl}^{-}$transport mechanism, likely $\mathrm{KCC} 2$, whereas the negative shift in glycine reversal potential observed in immature neurons indicates inhibition of a net inward $\mathrm{Cl}^{-}$transport system, likely to be the $\mathrm{Na}-\mathrm{K}-2 \mathrm{Cl}$ cotransporter. Unlike the case in CNS neurons, it appears that the function of $\mathrm{NKCC} 1$ dominates $\mathrm{Cl}^{-}$transport in wild-type DRG neurons because bumetanide produces a hyperpolarizing shift in $E_{\mathrm{GABA}}$ when $\mathrm{NKCC1}$ is present and $E_{\mathrm{GABA}}$ is shifted to more hyperpolarized values when $\mathrm{NKCC} 1$ is removed. This strong NKCC1 inward $\mathrm{Cl}^{-}$transport may overshadow a smaller bumetanide-sensitive component of transport.

The observed actions of bumetanide in the absence of NKCC1 suggest that some caution should be exercised in interpreting results from experiments examining the effect of this drug and other loop diuretics on transmembrane $\mathrm{Cl}^{-}$concentration and the physiological roles of distribution of this ion. The limitations of the usefulness of loop diuretics in studies examining $\mathrm{GABA}_{\mathrm{A}}$ receptor function and transmembrane $\mathrm{Cl}^{-}$distribution are further demonstrated by the past and present findings that these compounds inhibit the conductance of $\mathrm{GABA}_{\mathrm{A}}$ receptor channels (Figs. 1D, 2) (Nicoll, 1978; Inomata et al., 1988; Pearce, 1993; Korpi and Lud- dens, 1997). These problems with the experimental use of bumetanide (or furosemide) highlight the importance of the genetic model that we have used in the present study. Selective knock-out of the $\mathrm{NKCC} 1$ gene provides strong support, independent of pharmacological approaches, for a role of this transporter in regulation of the neuronal $\mathrm{Cl}^{-}$gradient. Using this method, we have now firmly established that $\mathrm{NKCC} 1$ activity strongly contributes to the depolarizing effects of GABA in primary sensory neurons.

As alluded to previously, the functional data obtained in sensory DRG neurons can very likely be extended to immature CNS neurons (cortical and hippocampal) that have intracellular $\mathrm{Cl}^{-}$ concentrations higher than the electrochemical potential equilibrium and exhibit GABA- or glycine-depolarizing responses (BenAri et al., 1989; Owens et al., 1996; Ehrlich et al., 1999). These GABA- or glycine-depolarizing responses observed in immature neurons coincide with high NKCC1 expression (Plotkin et al., 1997b). Hyperpolarizing GABA or glycine responses develop shortly after birth in concert with a decrease in intracellular $\mathrm{Cl}^{-}$ concentration because of a simultaneous decrease of NKCC1 expression (Plotkin et al., 1997b) and increase in KCC2 expression (Clayton et al., 1998; Lu et al., 1999).

This study did not reveal the existence of alternative pathways for $\mathrm{Cl}^{-}$accumulation. However, our experiments were performed in the absence of bicarbonate. Thus, we cannot exclude the possibility that, in the homozygote, bicarbonate could compensate and affect the direction and extent of GABA responses in vivo. It is important to note, however, that in CNS neurons such as GABAergic sensorimotor cortical neurons (Owens et al., 1996) and glycinergic lateral superior olive neurons (Ehrlich et al., 1999), furosemide induced a marked negative shift in the GABA or glycine reversal potential in the presence of bicarbonate or $\mathrm{CO}_{2}$, suggesting that $\mathrm{Cl}^{-}$accumulation via the cotransporter is indeed the basis for depolarizing GABA or glycine responses in immature neurons and that inhibition of this pathway does not result in any compensation by bicarbonate. Furthermore, we have shown that the absence of depolarizing GABA currents in homozygote NKCC1 mutant DRG neurons results in sensory perception defects, indicating one potential role of $\mathrm{Cl}^{-}$regulation via the $\mathrm{Na}-$ $\mathrm{K}-2 \mathrm{Cl}$ cotransporter in the somatosensory system.

$\mathrm{GABA}_{\mathrm{A}}$-mediated primary afferent depolarization and presynaptic inhibition are known to regulate the excitability of sensory terminals of both large (muscle) and fine (pain, temperature, and touch receptors) afferent fibers. Abnormal synaptic transmission of type $1 \mathrm{~A}$ afferent fibers to spinal cord motor neurons is likely to result in gait and movement coordination phenotypes. Spasticity and locomotion phenotypes definitely exist in the homozygote NKCC1 mutants. Knock-out mice were unable to remain on the rotorod for a substantial period of time because of motor uncoordination and spasticity (Fig. 6). Despite these differences, the knock-out mice made significant improvements over the course of the nine rotorod sessions. These results are consistent with the sensory neuron $\mathrm{Na}-\mathrm{K}-2 \mathrm{Cl}$ cotransporter playing an important role in motor coordination, but other factors are involved as well. For instance, it is difficult at this stage to sort out the contribution of the spinal cord and of the inner ear in the uncoordination phenotype. We have reported previously that disruption of the secretory $\mathrm{Na}-\mathrm{K}-2 \mathrm{Cl}$ cotransporter gene results in anatomical defects of the inner ear associated with an absence of $\mathrm{K}^{+}$secretion. These defects result in deafness and abnormal control of balance phenotypes (Delpire et al., 1999) that could contribute to poor rotorod performance.

Type $\mathrm{A} \delta$ and type $\mathrm{C}$ fibers are both involved in the perception of pain. Abnormal synaptic transmission in these fibers is likely to affect pain threshold. Because of the wide range of capacitance values for the neurons from which we recorded, it is likely that we examined somata of $\mathrm{A} \delta$ and $\mathrm{C}$ type neurons. Using the standard hot plate test to evaluate the pain threshold, we have shown that homozygote NKCC1 mutant mice display a significantly higher pain threshold when compared with their control or heterozygote littermates (Fig. 7). This result cannot be attributed to a complete 
absence of sensory perception or to a general apathy and lack of reflexes because the mice passed the general tests involved in the gross neurological screen. Therefore, this result clearly demonstrates that elimination of the $\mathrm{Na}-\mathrm{K}-2 \mathrm{Cl}$ cotransporter results in alteration of the processing of sensory signals. On the basis of the premise that primary afferent depolarization and presynaptic inhibition filter sensory noise, we propose that NKCC1 knock-out animals likely experience decreased sensory contrast resulting in a higher pain threshold. Our findings do not provide evidence of a strong causal link between the change in the sensory neuron transmembrane $\mathrm{Cl}^{-}$gradient and the increase in pain threshold. However, these observations indicate that the NKCC1 knock-out mice do experience alterations in pain perception that are consistent with what would be expected after alteration of GABAergic effects at primary afferent synapses. The change in pain thresholds that we observed is not caused by generalized hypokinesia or hypoflexia because the animals show vigorous retropulsive movement and reflexive response patterns. Interestingly, our data differ somewhat from experiments showing that intrathecal administration of GABA and $\mathrm{GABA}_{\mathrm{A}}$ receptor agonists increases the nociceptive threshold in rats (Hammond and Drower, 1984; Roberts et al., 1986) whereas bicuculline, a $\mathrm{GABA}_{\mathrm{A}}$ receptor antagonist, results in profound agitation. However, these studies examine the short-term effect of applying pharmacological agents in the spinal cord that can affect both postsynaptic and presynaptic neurons, and it is not clear whether the NKCC1 knock-out affects postsynaptic GABAergic responses in the spinal cord. In agreement with our data, these studies stress the important role of $\mathrm{GABA}_{\mathrm{A}}$-mediated transmission in peripheral sensation. In light of the nociception phenotype, it will be important to examine in future studies presynaptic inhibition in the NKCC1 knock-out mouse.

\section{REFERENCES}

Alvarez-Leefmans FJ, Gamiño SM, Giraldez F, Nogueron I (1988) Intracellular chloride regulation in amphibian dorsal root ganglion neurons studied with ion-selective microelectrodes. J Physiol (Lond) 406:225-246.

Alvarez-Leefmans FJ, Nani A, Marquez S (1998) Chloride transport, osmotic balance, and presynaptic inhibition. In: Presynaptic inhibition and neural control (Rudomin P, Romo R, Mendell LM, eds), pp 50-79. New York: Oxford UP.

Banfi S, Cornelli U, Fonio W, Dorigotti L (1982) A screening method for substances potentially active on learning and memory. J Pharmacol Methods 8:255-263.

Ben-Ari Y, Cherubini E, Corradetti R, Gaiarsa JL (1989) Giant synaptic potentials in immature rat CA3 hippocampal neurones. J Physiol (London) 416:303-325.

Choi S, Lovinger D (1996) Metabotropic glutamate receptor modulation of voltage-gated $\mathrm{Ca}^{2+}$ channels involves multiple receptor subtypes in cortical neurons. J Neurosci 16:36-45.

Clayton GH, Owens GC, Wolf JS, Smith RL (1998) Ontogeny of cation$\mathrm{Cl}^{-}$cotransporter expression in rat neocortex. Brain Res Dev Brain Res 109:281-292.

Crawley JN, Paylor R (1997) A proposed test battery and constellations of specific behavioral paradigms to investigate the behavioral phenotypes of transgenic and knockout mice. Horm Behav 31:197-211.

Delpire E, Lu J, England R, Dull C, Thorne T (1999) Deafness and imbalance associated with inactivation of the secretory $\mathrm{Na}-\mathrm{K}-2 \mathrm{Cl}$ cotransporter. Nat Gen 22:192-195.
Ehrlich I, Lohrke S, Friauf E (1999) Shift from depolarizing to hyperpolarizing glycine action in rat auditory neurones is due to age-dependent $\mathrm{Cl}^{-}$regulation. J Physiol (Lond) 520:121-137.

Flagella M, Clarke LL, Miller ML, Erway LC, Giannella RA, Andringa A, Gawenis LR, Kramer J, Duffy JJ, Doetschman T, Lorenz JN, Yamoah EN, Cardell EL, Shull GE (1999) Mice lacking the basolateral Na-K$2 \mathrm{Cl}$ cotransporter have impaired epithelial chloride secretion and are profoundly deaf. J Biol Chem 274:26946-26955.

Haas M, Forbush III B (1998) The Na-K-Cl cotransporters. J Bioenerg Biomembr 30:161-172.

Hammond DL, Drower EJ (1984) Effects of intrathecally administered THIP, baclofen and muscimol on nociceptive threshold. Eur J Pharmacol 103:121-125.

Hunter AJ, Hatcher J, Virley D, Nelson P, Irving E, Hadingham SJ, Parsons AA (2000) Functional assessments in mice and rats after focal stroke. Neuropharmacology 39:806-816.

Inomata N, Ishihara T, Akaike N (1988) Effects of diuretics on GABAgated chloride current in frog isolated sensory neurones. Br J Pharmacol 93:679-683.

Irwin S (1968) Comprehensive observational assessment: Ia. A systematic, quantitative procedure for assessing the behavioral and physiologic state of the mouse. Psychopharmacologia 13:222-257.

Kaplan MR, Plotkin MD, Brown D, Hebert SC, Delpire E (1996) Expression of the mouse Na-K-2Cl cotransporter, mBSC2, in the terminal IMCD, the glomerular and extraglomerular mesangium and the glomerular afferent arteriole. J Clin Invest 98:723-730.

Korpi ER, Luddens H (1997) Furosemide interactions with brain GABAA receptors. Br J Pharmacol 120:741-748.

Lu J, Karadsheh M, Delpire E (1999) Developmental regulation of the neuronal-specific isoform of $\mathrm{K}-\mathrm{Cl}$ cotransporter $\mathrm{KCC} 2$ in postnatal rat brains. J Neurobiol 39:558-568.

Mount DB, Delpire E, Gamba G, Hall AE, Poch E, Hoover Jr RS, Hebert SC (1998) The electroneutral cation-chloride cotransporters. J Exp Biol 201:2091-2102.

Nicoll RA (1978) The blockade of GABA mediated responses in the frog spinal cord by ammonium ions and furosemide. J Physiol (Lond) 283:121-132.

Owens DF, Boyce LH, Davis MBE, Kriegstein AR (1996) Excitatory GABA responses in embryonic and neonatal cortical slices demonstrated by gramicidin perforated-patch recordings and calcium imaging. J Neurosci 16:6414-6423.

Pearce RA (1993) Physiological evidence for two distinct GABAA responses in rat hippocampus. Neuron 10:189-200.

Plotkin MD, Kaplan MR, Peterson LN, Gullans SR, Hebert SC, Delpire E (1997a) Expression of the $\mathrm{Na}^{+}-\mathrm{K}^{+}-2 \mathrm{Cl}^{-}$cotransporter BSC2 in the nervous system. Am J Physiol 272:C173-C183.

Plotkin MD, Snyder EY, Hebert SC, Delpire E (1997b) Expression of the $\mathrm{Na}-\mathrm{K}-2 \mathrm{Cl}$ cotransporter is developmentally regulated in postnatal rat brains: a possible mechanism underlying GABA's excitatory role in immature brain. J Neurobiol 33:781-795.

Roberts LA, Beyer C, Komisaruk BR (1986) Nociceptive responses to altered GABAergic activity at the spinal cord. Life Sci 39:1667-1674.

Rogers DC, Fisher EM, Brown SD, Peters J, Hunter AJ, Martin JE (1997) Behavioral and functional analysis of mouse phenotype: SHIRPA, a proposed protocol for comprehensive phenotype assessment. Mamm Genome 8:711-713.

Rohrbough J, Spitzer NC (1996) Regulation of intracellular $\mathrm{Cl}^{-}$levels by $\mathrm{Na}^{+}$-dependent $\mathrm{Cl}^{-}$cotransport distinguishes depolarizing from hyperpolarizing $\mathrm{GABA}_{\mathrm{A}}$ receptor-mediated responses in spinal neurons. J Neurosci 16:82-91.

Russell JM (2000) Sodium-potassium-chloride cotransport. Physiol Rev 80:211-276.

Welkowitz J, Ewen RB, Cohen J (1982) Introductory statistics for the behavioral sciences. Orlando, FL: Academic.

Willis WD (1999) Dorsal root potentials and dorsal root reflexes: a double-edged sword. Exp Brain Res 124:395-421. 